\title{
Persepsi Konsumen Dalam Pembelian Motor Yamaha Fino Pada PD. Panca Motor Kota Jambi
}

\author{
Pupu Sopini \\ Fakultas Ekonomi Universitas Batanghari \\ Correspondence email: pupu.sopini@unbari.ac.id
}

\begin{abstract}
Abstrack. This research aims to know and analyze consumers ' perception of Yamaha Fino Motor purchase in PD dealers. Panca Motor Kota Jambi. Research methods used using descriptive analysis and data types are processed from primary data that is deployed on Yamaha Fino motorcycle users. Population and samples amounted to 101 people and were obtained from the number of motorcycles sales in 2018 with sample withdrawals using the census method. The theoretical approach used is the consumer perception theory of Yamaha Fino motor products. Indicators of consumer perception used consist of selection perception, organizing perception and achievement accomplishment. The results showed that consumer perception in Yamaha Fino motorcycle purchases was influenced by the organizing indicators perception with an average score of 408. Consumer perception in the purchase of Yamaha Fino motorcycles was influenced by family stimuli, the environment and the highest because of the promotion carried out by the motor dealers very well with a score of 443.
\end{abstract}

Keywords : consumer perception, purchase Yamaha Fino.

\section{Pendahuluan}

Kota Jambi adalah sebuah kota di Indonesia sekaligus merupakan Ibu Kota Provinsi Jambi, dengan memiliki luas sekitar $205,38 \mathrm{~km}^{2}$ dengan penduduknya berjumlah 604.378 jiwa (2019) dan cuaca berkisar $29 \mathrm{C}$ - 32 C. Kondisi wilayah kota Jambi tersebut dilengkapi dengan akses jalan yang tidak terlalu lebar dan juga tidak terlalu panjang. Salah satu alat transportasi yang sangat sesuai dan menjadi pilihan masyarakat adalah menggunakan kendaraan roda dua seperti sepeda motor. Setiap tahun pertumbuhan kendaraan bermotor roda dua terus mengalami peningkatan yang cukup signifikan di Kota Jambi. Berdasarkan data yang diolah BPS Kota Jambi dari tahun 2015 -2019, jumlah kendaraan roda dua pada tahun 2015 sebanyak 1.484 .455 unit, tahun 2016 berjumlah 1.549 .747 unit, tahun 2017 berjumlah 1.657.018 unit dan tahun 2018 berjumlah 1.776 .187 unit. Sedangkan informasi terbaru untuk tahun 2019 kendaraan roda dua di Kota Jambi berjumlah 1.882.425 unit. Berdasarkan data dari BPS tersebut, maka permintaan kendaraan roda dua di Kota Jambi sangat tinggi. Hal tersebut memberikan peluang bisnis yang menjanjikan bagi pelaku bisnis otomotif. Terdapat beberapa merek kendaraan roda dua diantaranya adalah Merek Honda, Suzuki, Kawasaki dan Yamaha yang tersebar pada beberapa dealer di Kota Jambi. Bisnis tersebut akan berjalan dengan sukses tergantung dari manajemen perusahaan dalam pemasaran produk tersebut. Bagian pemasaran harus memperhatikan perilaku konsumen dalam menjalankan strategi promosinya, karena pilihan merek kendaraan roda dua akan jatuh ke tangan konsumen berdasarkan perilaku pembelian konsumen. Perilaku konsumen merupakan suatu proses yang berkaitan erat dengan proses pembelian, pada saat itu konsumen melakukan aktifitas- aktifitas seperti melakukan pencarian, penelitian, dan pengevaluasian produk. Perilaku konsumen merupakan hal-hal yang mendasari konsumen untuk membuat keputusan pembelian. Salah satu cara untuk mengetahui perilaku konsumen adalah dengan menganalisis persepsinya terhadap produk. Dengan persepsi konsumen, perusahaan dapat mengetahui hal-hal apa saja yang menjadi kekuatan atau kelemahan, kesempatan ataupun ancaman bagi produk yang dipasarkan. Hal ini karena persepsi konsumen merupakan salah satu faktor internal konsumen yang mempengaruhinya mengambil keputusan (Foedjiawati, Hatane Semuel. 2007: 6).

PD. Panca Motor adalah Perusahaan dagang yang bergerak dibidang perdagangan otomotif (sepeda motor, suku cadang, dan aksesoris) dengan Merek Yamaha. Perusahaan tersebut mulai beroperasi pada tahun 2009 bertempat di Payo Selincah, Kec. Jambi Timur Kota Jambi. Dealer PD. Panca Motor menjual beberapa motor diantaranya adalah motor matic yang menjadi pilihan utama masyarakat dengan kondisi semakin padatnya arus lalu lintas di Kota Jambi. Jenis motor matic dari Yamaha yaitu Yamaha Mio, Yamaha Mio Soul, Yamaha Mio Sporty, Yamaha Mio Fino, Yamaha Fino. Dari beberapa jenis motor matic Yamaha, motor Yamaha Fino merupakan jenis matic yang kurang diminati oleh masyarakat. Pada tahun 2016 Yamaha Fino melakukan perubahan dari sektor mesin yang berkapasitas $125 \mathrm{cc}$ dan dilengkapi dengan teknologi Blue Core, Yamaha Fino juga dilengkapi dengan fitur ECO merupakan indikator yang semakin hemat bahan bakar. Walaupun sudah banyak mendapatkan perubahan, Secara kuantitas penjualan Yamaha lebih sedikit dibandingkan dengan motor matic Honda Scopy yang begitu fantastis jumlah penjualannya. Berikut data perbandingan dan perkembangan 
Tabel 1

Perkembangan Volume Penjualan Yamaha Fino dan Honda Scopy Tahun 2014-2018

\begin{tabular}{|l|r|r|r|r|}
\hline \multicolumn{1}{|c|}{ Periode } & Fino (unit) & Perkembangan (\%) & Scoopy (unit) & \multicolumn{1}{c|}{ Perkembangan (\%) } \\
\hline 2014 & 126 & - & 557 & - \\
\hline 2015 & 131 & 3,96 & 609 & 9,33 \\
\hline 2016 & 167 & 27,48 & 672 & 10 \\
\hline 2017 & 132 & $(20,95)$ & 720 & 7,14 \\
\hline 2018 & 101 & $(23,48)$ & 755 & 4,86 \\
\hline Rata-rata & 131 & $(2,59)$ & 663 & 6,26 \\
\hline
\end{tabular}

Sumber : Dealer Yamah dan Honda Jambi

Berdasarkan tabel diatas dapat dilihat, bahwa perkembangan penjualan Yamaha Fino selama tahun 2014-2018 dengan rata-rata berjumlah 131 unit dan perkembangan rata-rata mengalami penurunan sebesar $2,59 \%$. Sedangkan jenis Scoopy merek Honda selama lima tahun terakhir memiliki rata-rata penjualan sebesar 663 unit dan perkembangan rata-ratanya sebesar $6,26 \%$. Hal tersebut tentu sangat berbanding terbalik kondisi penjualannya antara Yamaha Fino dengan Scoopy produk dari Honda. Terjadinya penurunan perkembangan jumlah unit motor Yamaha Fino akan berdampak menurunnya pendapatan dari hasil penjualan pada dealer motor tersebut. Hal ini berarti minat konsumen untuk membeli dan memiliki kendaraan roda dua Yamaha Fino juga sangat menurun. Penurunan daya beli konsumen selain dipengaruhi faktor eksternal juga dapat dipengaruhi oleh faktor internal konsumen tersebut. Perilaku konsumen tersebut dapat kita amati melalui teori perilaku konsumen. Perilaku konsumen adalah tindakan-tindakan produk dan jasa, termasuk didalamnya adalah proses keputusan yang mengawali serta mengikuti tindakan pembelian tersebut. Tindakan tersebut adalah terlibat secara langsung dalam proses memperoleh, mengkonsumsi bahkan membuang atau tidak jadi menggunakan suatu produk atau jasa tersebut (Engel, J.F. et.al. 1994:97). Menurut Kotler dan Keller (2007:214-226), faktor-faktor yang mempengaruhi perilaku konsumen adalah :

1. Faktor Kebudayaan, faktor-faktor kebudayaan mempunyai pengaruh yang paling luas dan mendalam terhadap perilaku konsumen. Pemasar harus memahami peran yang dimainkan oleh kultur, sub-kultur, dan kelas sosial pembeli.

2. Faktor Sosial, perilaku seorang konsumen yang dipengaruhi oleh faktor-faktor sosial seperti perilaku kelompok acuan (kelompok referensi), keluarga, serta peran dan status sosial dari konsumen.

3. Faktor Pribadi, keputusan seorang pembeli juga dipengaruhi oleh karakteristik pribadi, yaitu usia pembeli dan tahap siklus hidup pembeli, pekerjaan, kondisi ekonomi. Gaya hidup, serta kepribadian dan kondisi ekonomi, gaya hidup, serta kepribadian dan konsep diri pembeli.

4. Faktor Psikologis, pilihan pembelian seseorang dipengaruhi pula oleh empat faktor psikologis utama, yaitu motivasi, persepsi, pengetahuan (learning), serta keyakinan dan sikap.

Persespsi konsumen adalah peroses ketika seseorang memilih, mengorganisasi dan menginterprestasikan informasi yang datang menjadi suatu arti tersendiri untuk menciptakan gambaran secara keseluruhan. (Kotler, 2007:229). Persepsi konsumen tidak hanya bergantung pada rangsangan fisik tapi juga rangsangan yang berhubungan dengan lingkungan sekitar dan keadaan individu yang bersangkutan (Kotler dan Keller, 2016:228). Persepsi merupakan hasil pemaknaan seseorang terhadap stimulus atau kejadian yang diterimanya berdasarkan informasi dan pengalamannya terhadap rangsangan tersebut. Ketika seseorang menerima persepsi mengenai suatu produk dengan baik, maka ia akan memiliki persepsi bahwa produk tersebut baik dan akan mencoba produk tersebut. Faktor-faktor yang mempengaruhi persepsi konsumen menurut Donni Juni Priansa (2017:153) terdiri dari :

a. Objek yang dipersepsi

b. Objek menimbulkan stimulus mengenai alat indera atau reseptor. Stimulus dapat datang dari luar individu yang mempersepsi, tetapi juga dapat datang dari dalam individu yang bersangkutan yang langsung mengenai syaraf penerima yang bekerja sebagai reseptor.

c. Alat indera, syaraf dan susunan syaraf, yang merupakan alat untuk menerima stimulus dan diterima reseptor ke pusat susunan syaraf yaitu otak sebagai pusat kesadaran serta sebagai alat untuk mengadakan respon diperlukan motoris yang dapat membentuk persepsi seseorang.

d. Perhatian, yaitu merupakan langkah utama sebagai suatu persiapan dalam rangka mengadakan persepsi. Perhatian merupakan pemusatan atau konsentrasi dari seluruh aktivitas individu yang ditujukan kepada sekumpulan objek.

Indikator pembentukan persepsi Menurut setiadi (2010) dalam Donni Juni Priansa (2017:151) yaitu :

1. Seleksi Persepsi, terjadi ketika konsumen menangkap dan memilih stimulus berdasarkan berbagai informasi yang ada didalam memorinya.

2. Pengorganisasian Persepsi, berarti bahwa konsumen mengelompokan informasi dari berbagai sumber ke dalam pengertian yang menyeluruh untuk 
memahami lebih baik dan bertindak atas pemahaman itu.

3. Interprestasi Persepsi, memberikan interprestasi atas stimulus yang diterima konsumen.

Menurut Adler dan Rodman (2010:76) mengemukanan terdapat 3 indikator persepsi yaitu terdiri dari:

1. Seleksi Persepsi, merupakan tindakan memperhatikan rangsangan tertentu dalam lingkungan. Konsumen secara tidak sadar banyak memilih aspek-aspek lingkungan mana (stimuli) yang mereka rasakan. Stimuli mana yang terpilih tergantung pada dua faktor utama selain sifat stimuli itu sendiri, yaitu : (a) Pengalaman konsumen sebelumnya, karena hal tersebut mempengaruhi harapan-harapan mereka (apa yang mereka siapkan atau "tetapkan" untuk dilihat); (b) Motif mereka pada waktu itu (kebutuhan, keinginan, minat).

2. Organisasi, yaitu proses mengorganisasikan dengan merangkainya sehingga menjadi bermakna.

3. Interprestasi, adalah proses subjektif dari menjelaskan persepsi ke dalam cara yang kita mengerti. Setelah terbentuk pengertian atau pemahaman, terjadilah penilaian dari individu.

Karakteristik persepsi konsumen Donni Juni Priansa (2017:153) yaitu sebagai berikut :

1. Bersifat selektif, yaitu konsumen memilih sejumlah keterbatasan dalam hal kapasitas atau kemampuan merak dalam memperoleh semua informasi dari lingkungan.

2. Terorganisir dan teratur, suatu rangsangan atau pendorong tidak bias dianggap terisolasi dari perangsang lain.

3. Subjektif persepsi, merupakan fungsi dari faktor pribadi yang berhubungan dengan perasaan, kebutuhan, nilai-nilai, motif, pengalaman, masa lalu, pola pikir, dan kepribadian seseorang.

4. Pengaruh lingkungan, persepsi sangat dipengaruhi oleh lingkungan yang ada yaitu tumbuh dan berkembang.

Persepsi sering kali timbul karna adanya informasi yang didapatkan oleh konsumen terhadap suatu produk atau jasa yang di lihat dari iklan produk, informasi dari kelauarga, teman, atau produk itu sendiri. Dampaknya adalah bagaimana konsumen menginterprestasikan suatu produk yang dia sukai.

\section{Metode}

Jenis data penelitian yang digunakan adalah data deskriptif kualitatif dengan menggunakan data primer yang diolah melalui kuisioner persepsi konsumen dalam pembelian motor Yamaha Fino. Populasi dalam penelitian ini adalah jumlah penjualan motor Yamaha Fino pada dealer PD. Panca Motor Jambi sebanyak 101 unit, dengan asumsi 1 unit motor di beli oleh satu orang sehingga jumlah konsumen sebanyak 101 orang yang melakukan pembelian motor pada tahun 2018. Jumlah konsumen tersebut dijadikan sampel penelitian, dengan metode penarikan jumlah sampel menggunakan metode sensus yaitu sampel sama dengan jumlah populasi. Penyebaran data kuesioner dilakukan melalui fasilitas google formulir kepada konsumen Yamaha Fino sejumlah 101 orang responden yang menggunakan motor Yamaha Fino di Kota Jambi. Analisis data yang digunakan untuk menilai rata-rata persepsi konsumen pembelian motor Yamaha Fino yaitu dengan menggunakan skala likert. Kemudian dilakukan perhitungan dari setiap jawaban yang diberikan oleh responden dimana setiap jawaban diberi bobot nilai dan untuk selanjutnya dapat ditarik kesimpulan. Dari hasil jawaban responden maka ditentukan rentang skala untuk menentukan kategori penafsiran hasil data deskriptif pada setiap jawaban dari pertanyaan yang diajukan kepada responden dengan rumus : Rs $=((\mathrm{Rm}-\mathrm{Ri})) / \mathrm{n}$, dimana $:$ Rs $=$ Rentang Skala, $\mathrm{Rm}=$ Skor Tertinggi, $\mathrm{Ri}=$ Skor Terendah, $\mathrm{n}=$ Jumlah Item. Jika diketahui rentang skala setiap kriteria/indikator, maka diperoleh kriteria penilaian : 1. Sangat Tidak Setuju, 2. Tidak Setuju, 3. Cukup Setuju, 4. Setuju dan 5. Sangat Tidak Setuju. Kemudian dihitung rata-rata (Mean) dari setiap indikatornya. Setelah diketahui Rata-ratanya secara keseluruhan, kemudian dilakukan analisa deskriptif berdasarkan teori pendukung dan deskripsi karakteristik responden pada PD. Panca Motor di Kota Jambi.

\section{Hasil}

Responden sebanyak 101 orang dalam penelitian ini terdiri dari perempuan 21 orang $(20,79 \%)$ dan lakilaki sebanyak 80 orang $(79,21 \%)$, Karakteristik responden berdasarkan usia, yaitu pada usia 31-40 tahun sebanyak $86,9 \%$, usia 40 tahun sebnyak $12,1 \%$ dan usia $<21-30$ sebanyak 1\% serta jumlah <20 tahun tidak ditemukan. Karakteristik responden berdasarkan pekerjaan adalah wiraswasta dengan 57 orang $(56,5 \%)$. Jumlah pekerjaan responden lain-lain sebanyak 27 orang $(26,7 \%)$ dan pekerjaan responden sebagai PNS berjumlah 17 orang $(16,8 \%)$. Karakteristik responden menurut pendapatan yaitu >Rp.3.000.000 sebanyak 48 (47,5\%), pendapatan Rp.2.000.000-Rp.2.999.999 sebanyak 45 orang (44,5\%), dan pendapatan Rp.1.500.000-Rp.1.999.999 sebanyak 8 orang (8\%). Hasil jawaban responden mengenai persepsi konsumen dalam pembelian motor Yamaha Fino, berdasarkan indikator persepsi yaitu seleksi persepsi, pengorganisasian persepsi dan interprestasi persepsi yang telah diolah peneliti dapat dilihat pada tabel 2 berikut ini : 
Tabel 2

Jawaban Responden Terhadap Persepsi Konsumen Motor Yamaha Fino Pada PD. Panca Motor Kota Jambi

\begin{tabular}{|c|c|c|c|}
\hline No & Pernyataan & Skor & Keterangan \\
\hline \multicolumn{4}{|c|}{ Seleksi persepsi } \\
\hline 1 & Harga yang dibayarkan sesuai dengan manfaat yang didapatkan & 454 & Sangat setuju \\
\hline 2 & Membeli sepeda motor Yamah Fino sesuai dengan kebutuhan saya berkendara & 370 & Setuju \\
\hline 3 & $\begin{array}{l}\text { Membeli sepeda motor Yamaha Fino sesuai dengan kebutuhan saya untuk bergaya } \\
\text { mengikuti zaman sekarang }\end{array}$ & 407 & Setuju \\
\hline 4 & $\begin{array}{l}\text { Motor Yamaha Fino berguna untuk kedepannya dan merupakan kebutuhan sehari- } \\
\text { hari berkendara }\end{array}$ & 375 & Setuju \\
\hline \multirow[t]{2}{*}{5} & Memenuhi kebutuhan dalam menunjang gaya hidup saya & 400 & Setuju \\
\hline & Rata-rata & 401,2 & Setuju \\
\hline \multicolumn{4}{|c|}{ Perngorganisasian persepsi } \\
\hline 6 & Keluarga merupakan alasan dalam membeli sepeda motor Yamaha Fino & 417 & Setuju \\
\hline 7 & Lingkungan mempengaruhi untuk melakukan pembelian sepeda motor Yamaha Fino & 376 & Setuju \\
\hline 8 & Iklan Yamaha Fino memiliki daya Tarik dalam penyampain produk & 396 & Setuju \\
\hline 9 & $\begin{array}{l}\text { Promosi penjualan motor Yamaha Fino memiliki daya Tarik untuk melakukan } \\
\text { pembelian }\end{array}$ & 443 & Sangat setuju \\
\hline & Rata-rata & 408 & Setuju \\
\hline \multicolumn{4}{|c|}{ Interprestasi persepsi } \\
\hline 10 & Saya membeli produk Yamaha Fino atas rekomendasi dari orang-orang sekitar & 383 & Setuju \\
\hline 11 & $\begin{array}{l}\text { Kualitas merek yang ditawarkan Yamaha Fino membuat saya tertarik untuk } \\
\text { melakukan pembelian }\end{array}$ & 357 & Setuju \\
\hline 12 & $\begin{array}{l}\text { Informasi tentang Yamaha Fino yang mudah didapatkan membuat saya yakin untuk } \\
\text { melakukan pembelian }\end{array}$ & 369 & Setuju \\
\hline 13 & $\begin{array}{l}\text { Banyaknya pelayanan yang ditawarkan membuat saya mau untuk membeli sepeda } \\
\text { motor Yamaha Fino }\end{array}$ & 370 & Setuju \\
\hline \multirow[t]{4}{*}{14} & $\begin{array}{l}\text { Harga tidak menjadi masalah dalam melakukan pembelian sepeda motor Yamaha } \\
\text { Fino }\end{array}$ & 454 & Sangat setuju \\
\hline & Rata-rata & 386,6 & Setuju \\
\hline & Jumlah & 5,571 & \\
\hline & Rata-rata & 397,1 & Setuju \\
\hline
\end{tabular}

Sumber :data diolah

Penjelasan dari tabel diatas diketahui skor ratarata jawaban responden sebesar 397,1 menunjukan bahwa persepsi konsumen mengenai kendaraan roda dua Yamaha Fino dinilai setuju oleh responden berdasarkan beberapa indikator persepsi konsumen yaitu seleksi persepsi, pengorganisasian persepsi dan interprestasi prestasi. Jawaban responden terhadap indikator seleksi persepsi menghasilkan rata-rata sebesar 401,2 yaitu pada rentang sekala setuju, hal ini menunjukkan bahwa persepsi konsumen terhadap item indikator tersebut adalah baik terutama pada harga yang dibayarkan sesuai dengan manfaat yang diterima dari penggunaan motor Yamaha Fino sebesar 454 dengan rentang sangat setuju (persepsi konsumen sangat baik). Pada indikator pengorganisasian persepsi menunjukkan nilai rata-rata skor sebesar 408 pada rentang pernyataan setuju atau persepsi konsumen baik berdasarkan item pernyataan bahwa persepsi konsumen dipengaruhi oleh keluarga, lingkungan dan yang tertinggi karena adanya promosi yang dilakukan dealer motor tersebut sangat baik dengan skor 443 .
Interprestasi persepsi menghasilkan rata-rata skor sebesar 386,6, yang diperoleh informasi bahwa persepsi konsumen terbentuk karena dipengaruhi oleh rekomendasi dari lingkungan sekitar mengenai merek, kualitas layanan, informasi kualitas produk dan harga produk Yamaha Fino. Item tertinggi terletak pada pernyataan interprestasi persepsi mengenai harga produk tidak terlalu masalah dengan skor rata-rata 454 yang menunjukkan sangat setuju dan sangat baik. Dengan demikian hasil penilaian penelitian ini secara keseluruhan memberikan gambaran bahwa hasil penjualan motor Yamaha Fino yang berfluktuasi menurun sebagai akibat faktor psikologis lain, yaitu adanya stimuli pemasaran berupa bauran pemasaran yang meliputi produk, harga, tempat/distributor dan promosi (Kotler, 2000;34).

\section{Simpulan}

Kesimpulan yang dapat diambil dari penelitian ini, bahwa persepsi konsumen dalam pembelian motor Yamaha Fino dipengaruhi oleh indikator pengorganisasian persepsi dengan skor rata-rata 408. Hal 
ini berarti konsumen mengelompokan informasi dari berbagai sumber ke dalam pengertian yang menyeluruh untuk memahami lebih baik dan bertindak atas pemahaman itu. Sebelum memutuskan pembelian motor Yamaha Fino. Pengaruh keluarga, lingkungan dan yang tertinggi karena adanya promosi yang dilakukan dealer motor tersebut sangat baik dengan skor 443 .

\section{Daftar Pustaka}

Adler dan Rodman. 2010. Understanding Human Comunication. Terjemahan Agus Darma. Jakarta. Erlangga.

Agustina Shinta, M.P (2011). Manajemen Pemasaran. Malang. UB press.

Amstrong dan Kotler (2014). Strategi pemasaran. Surabaya : Gramedia

Donni Juni Priansa (2017). Perilaku konsumen. Alfabeta. Bandung.

Engel, J.F. et.al. 1994. Consumer Behavior Jilid 1, Alih Bahasa Budiyanto. Jakarta:Binarupa Aksara.

Istijianto (2009). Metodologi penelitian. Jakarta. Gramedia.

Kotler, Philip. 2000. Manajemen Pemasaran. Jakarta: Prenhallindo.

Kotler, Philip dan Kevin Lane Keller. 2008. Manajemen Pemasaran, Jilid 1. Jakarta: Erlangga.

Setiadi, Nugroho (2015). Perilaku Konsumen. Edisi 6. Jakarta: Prenamedia Group.

Tourism and Hospitality Essentials (THE) Journal, Vol. 8, No. 1, 2018 - 32 